\title{
Urgences
}

\section{Le train de dire}

\section{Bernard Boucher}

Numéro 1, 2e trimestre 1981

URI : https://id.erudit.org/iderudit/025002ar

DOI : https://doi.org/10.7202/025002ar

Aller au sommaire du numéro

Éditeur(s)

Urgences

ISSN

0226-9554 (imprimé)

1927-3924 (numérique)

Découvrir la revue

Citer ce document

Boucher, B. (1981). Le train de dire. Urgences, (1), 10-13.

https://doi.org/10.7202/025002ar

Ce document est protégé par la loi sur le droit d'auteur. L’utilisation des services d'Érudit (y compris la reproduction) est assujettie à sa politique d'utilisation que vous pouvez consulter en ligne.

https://apropos.erudit.org/fr/usagers/politique-dutilisation/
Cet article est diffusé et préservé par Érudit.

Érudit est un consortium interuniversitaire sans but lucratif composé de l'Université de Montréal, l'Université Laval et l'Université du Québec à Montréal. Il a pour mission la promotion et la valorisation de la recherche. https://www.erudit.org/fr/ 
BERNARD BOUCHER

Le train de dire 
en cavale de cheval déraisonné

en cavale d'écriture

planter dans les fossés du temps

des augures pour les survivants

raviner le sens des mots

fixer le mal des tripes

l'air flottant entre les veines et la peau

pour dire

juste pour dire

dénier la main

arrondir les silences éventés

formuler des algèbres libidinales

baisser les culottes de la retenue avoir la vie pudique 
n'abolissons la peine de mots

l'échafaud du verbe

la potence des autres

comme on n'osera jamais

abolir la peine d'amour

sur le pont des satyres

le soir est humide

nous grelottons des yeux

en murmure devant des miroirs éternels

bâtir péniblement son ermitage où s'étirera sinueusement la voie de dire roulera le train d'écrire 
peuple en file et mise de fond file de chefs et force de dire la mise en mot

comme l'arbre s'effeuillerait tout le long d'un chemin de fer au creux de l'estomac

se mettre à mot et à sang

le saccage des idées reçues

le saccage de s'écrier

le saccage antagoniste d'être seul d'être tous seuls universellement

sur le pont des petits trains le soir est sordide nous frissonnons du coeur sans croire que ce soit réaliste mais demain nous verrons que la mise à mot entame un quotidien bien réel 